Piotr Ciski*

\title{
Droga Cybercomu w Polsce, czyli budowa efektywnego modelu biznesowego spółki zależnej kapitałowo
}

\section{Profil działalności}

Cybercom jest giełdową spółką technologiczną IT, wspierającą kluczowe firmy i organizacje w wykorzystywaniu szans płynących z użycia nowych technologii informatycznych. Firma specjalizuje się w dostarczaniu usług $\mathrm{w}$ ramach całego ekosystemu usług telekomunikacyjnych, połączonych urządzeń itd.

Rynkiem macierzystym Cybercomu jest region nordycki, na którym istnieje od 1995 r. Firma posiada również centra outsourcingowe w Polsce i w Indiach. Oddział polski powstał w roku 1997 i, oprócz outsourcingu usług informatycznych, dostarcza rozwiązania na rynek lokalny oraz rynek zachodnioeuropejski, w tym do Niemiec, Szwajcarii, Francji, Wielkiej Brytanii czy Belgii.

Cybercom jest notowany na giełdzie NASDAQ OMX Stockholm od 1999 r. Centrala grupy znajduje się w Sztokholmie, grupa liczy 1400 pracowników w 8 krajach. W Polsce firma posiada biura w Warszawie i w Łodzi i zatrudnia około 100 pracowników.

\footnotetext{
* Piotr Ciski - dyrektor zarządzający Cybercom Poland Sp. z o.o.
} 
Działalność Cybercomu prowadzona jest $\mathrm{w}$ trzech segmentach geograficznych: w Szwecji, Finlandii i w obszarze międzynarodowym. Szwecja jest największym samodzielnym segmentem, z 76\% udziałem w sprzedaży (07/2011-06/2012). W $2011 \mathrm{r}$. sprzedaż osiągnęła poziom 1,5 mld koron szwedzkich, a zysk operacyjny (EBITDA) wyniósł 65 mln koron szwedzkich.

Oferta Cybercomu jest podzielona na 3 sektory: Connected Engineering, Connectivity Management, Digital Solutions. Wiedza i doświadczenie w tych obszarach sprawiają, że firmie od wielu lat powierzane jest świadczenie usług i realizowanie projektów dla wielu znanych firm międzynarodowych, takich jak: Alma Media, Ericsson, Millicom, MTV Oy, SAAB, Sony Mobile, ST-Ericsson, TeliaSonera, Volvo and Volvo Car Corporation.

Cybercom polski, podobnie jak grupa poza Polską, dostarcza usługi IT w różnych modelach działania, takich jak: doradztwo i outsourcing IT, w tym wsparcie procesów biznesowych i analizy rozwiązań, projektowanie systemów i tworzenie systemów „,pod klucz”, integracja i wdrażanie rozwiązań, tworzenie strategii testowych, automatyzacja testów i kontrola jakości, szkolenia technologiczne i procesowe, własne R\&D, w tym weryfikacja koncepcji czy studia wykonalności, a także outsourcing wykwalifikowanego personelu IT.

Spółka współpracuje z firmami sektora telekomunikacyjnego, przedsiębiorstwami przemysłowymi, z branży bankowość i finanse, a także z handlu, logistyki, mediów czy wreszcie z sektora publicznego. Główne specjalizacje technologiczne to: wyspecjalizowane rozwiązania telekomunikacyjne, tworzenie systemów typu klient/serwer i portalowych w technologiach NET i Java Enterprise, rozwiązania mobilne, dla platform Android, iOS czy Windows Phone, a także rozwiązania zaawansowane systemu, wbudowane, oparte na platformie Linux, rozwiązania bazodanowe oparte na MS SQL Server czy Oracle. Ważną gałęzią technologiczną firmy są także rozwiązania z zakresu automatyki testów, w tym tworzenie zaawansowanych narzędzi wspierających procesy testowe. 


\section{Specyfika rynku polskiego}

Rynek polski na tle innych rynków europejskich jest w dalszym ciągu słabo rozwinięty. Wydatki na sprzęt IT (hardware) stanowią ponad 50\% wartości całego rynku, w dalszej kolejności pojawiają się wydatki na usługi (services), a najmniejszą wartość stanowią wydatki na oprogramowanie i licencje (software).

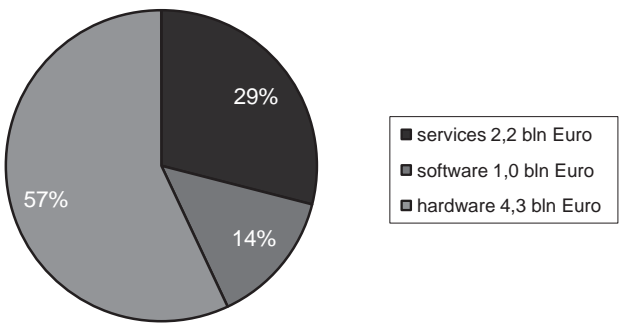

Wykres 1. Struktura polskiego rynku komputerowego Źródło: Computerworld 2011

Taka struktura rynku uzasadniona jest przede wszystkim tym, że Polska, w odróżnieniu od innych krajów europejskich, stosunkowo niedawno zaczęła inwestować w infrastrukturę (nadrabiamy opóźnienie w stosunku do reszty krajów rozwiniętych). Inwestycje w infrastrukturę oznaczają zarówno zakup komputerów, jak i zakup sprzętu telekomunikacyjnego. Warto zwrócić uwagę, że dynamika wydatków na hardware jest dużo niższa niż dynamika wydatków na usługi i licencje. Niewątpliwie jest to dobra informacja dla tych firm, które działają w sektorze usług. Specyfiką rynku polskiego jest obecność kilku dużych firm, takich jak Asseco, Comarch czy Sygnity, które starają się całkowicie zdominować polski rynek, w szczególności rynek zamówień publicznych. Dodatkowo na rynku obecne są duże firmy międzynarodowe, takie jak IBM czy Hewlett Packard, które świadcząc usługi informatyczne, oferują kompletne rozwiązania (turn-key solution), które obok tworzenia systemów „pod klucz” oferują sprzedaż sprzętu, 
oprogramowania, a także usługi doradcze i wdrożeniowe. Oprócz tych dużych graczy na rynku pojawiają się małe i średnie firmy konkurujące ze sobą, jednak to te największe, najbardziej rozpoznawalne marki mają największy wpływ na rynek.

Dodatkowo na rynku polskim istnieją spółki, które świadczą usługi offshoringowe. Cybercom Poland w początkowej fazie swojej działalności również należał do tego rodzaju spółek. Domeną takich spółek jest przede wszystkim działalność eksportowa. Klienci, wybierając spółki w Polsce, kierują się przede wszystkim dobrą jakością usług oraz konkurencyjną ceną w porównaniu do innych krajów europejskich. Trudno jednak mówić o konkurencyjności polskich firm offshoringowych w porównaniu do firm z Chin, Indii czy nawet Ukrainy i Rosji, zwłaszcza gdy bierze się pod uwagę jedynie cenę usługi. Jeśli jednak weźmiemy pod uwagę stosunek jakości oferowanej usługi do ceny, to wówczas polski rynek staje się wyjątkowo atrakcyjny, w związku z czym popyt na tego typu usługi nie maleje. Wiele firm umocniło swoją pozycję na rynku właśnie dzięki współpracy z dużymi graczami, m.in. Ericpol stał się dużym graczem offshoringowym, aż 70\% jego sprzedaży stanowi sprzedaż eksportowa.

\section{Początki działalności Cybercomu na polskim rynku}

Spółka rozpoczęła działalność w 1997 r. z siedzibą w Warszawie pod nazwą Sigma Poland, jako dostawca zasobów IT na rynek szwedzki. W roku 2001 Sigma AB - jedyny właściciel spółki polskiej, podzielił się na 3 spółki giełdowe: Epsilon, Teleca i „nowa” Sigma. Polska część przeszła w ręce Teleca AB.

Pierwsze lata działalności Teleca Sp. z o.o obejmowały głównie kontrakty skupiające się na dostarczeniu wykwalifikowanej kadry IT do wykonywania zadań w siedzibie klienta. Bezpośrednim klientem dla spółki był wtedy w większości wypadków klient wewnętrzny, czyli szwedzkie i angielskie oddziały spółki. A z kolei ich docelowymi klientami byli wiodący szwedzcy i fińscy producenci oprogramowania dla 
szeroko pojętej telekomunikacji oraz operatorzy o zasięgu globalnym. Prowadzona w tym czasie działalność była działalnością stricte konsultingową i miała wiele cech agencji dostarczającej pracowników tymczasowych, w tym wypadku wysokokwalifikowanej kadry IT, w tym architektów rozwiązań, programistów na różnych poziomach doświadczenia, a także wyspecjalizowanych testerów.

W latach 2004-2007 spółka doświadczyła bardzo intensywnego rozwoju. Okres ten zapoczątkował pierwszą fazę dojrzewania organizacji. W tych latach firma po raz pierwszy uzyskała certyfikację ISO 9001:2000, udowadniając tym samym, że jest organizacją dojrzałą, działającą w sposób zorganizowany i procesowy.

W roku 2005 spółka, zdobywając coraz więcej zamówień oraz osiągając coraz lepsze wyniki, otworzyła drugi oddział w Lodzi. Fakt ten zapoczątkował rozwój firmy w kierunku stania się organizacją samodzielnie dostarczającą usługi IT wytwarzane we własnych siedzibach. O wyborze Łodzi zadecydowało dogodne położenie geograficzne, szeroki dostęp do wykwalifikowanej kadry, a także fakt, że jest to lokalizacja tańsza w porównaniu do ulokowanej w Warszawie centrali firmy.

Oba biura spółki wkrótce musiały zostać poddane certyfikacji przez wiodących producentów rozwiązań dla telekomunikacji, aby móc już wtedy dostarczać oprogramowanie/usługi dla tychże firm. Certyfikat ISO (stale utrzymywany) oraz profesjonalne przygotowanie właściwego środowiska pracy, a także wszystkich niezbędnych zabezpieczeń, umożliwiło uzyskanie certyfikatu. Zatrudnienie w spółce zbliżało się do 100 osób.

W roku 2006, w związku z planowanym podziałem grupy będącej w 100\% właścicielem spółki, firma zmieniła nazwę na auSystems. Teleca pozostaje spółką giełdową, jednocześnie czynione były starania o doprowadzenie do debiutu giełdowego lub sprzedaży grupy auSystems, do której już wtedy należy oddział polski.

Wykres 2 na przykładzie wyników finansowych oraz liczby zatrudnionych osób obrazuje rozwój organizacji. Od 2004 r. zauważyć można znaczny wzrost, który trwał nieprzerwanie do roku 2007. W przełomowym 2007 r. cała spółka trafiła w ręce grupy Cybercom. Od tego momentu zaczynają się najnowsze dzieje firmy, działającej już pod nazwą Cybercom Poland. 


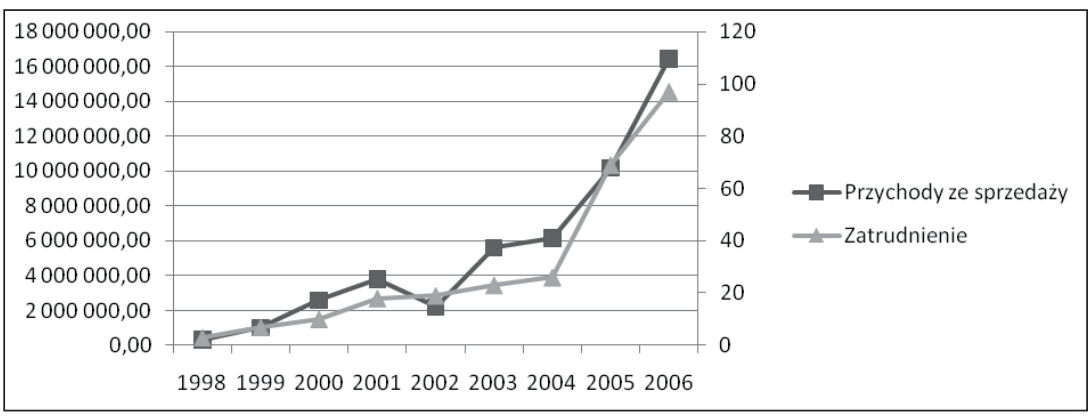

Wykres 2. Przychody ze sprzedaży i zatrudnienie w latach 1998-2006

Źródło: opracowanie własne

\section{Ewolucja grupy Cybercom}

Cybercom powstał w 1995 r., a rok później otworzył swoje biuro w Sztokholmie. Podczas pierwszych lat istnienia pozostawał małą firmą, zatrudniającą kilkudziesięciu pracowników. Pierwszy przełom nastąpił w roku 1998, kiedy to liczba pracowników osiągnęła 200 osób. Już rok później Cybercom zadebiutował na giełdzie w Sztokholmie - Stockholm Stock Exchange (aktualnie NASDAQ OMX Stockholm Exchange). Zmianom tym towarzyszył szybki wzrost firmy, która na koniec 1999 r. liczyła już 270 pracowników. Kolejne lata przyniosły stabilizację, ale również znaczne spowolnienie tempa wzrostu.

W roku 2006 Cybercom był wciąż średniej wielkości spółką IT, operującą głównie w Sztokholmie, pośród wielu podobnych jej podmiotów. Wkrótce jednak miało się to zmienić. Decyzją właścicieli firmy zarząd rozpoczął trwający kilka lat proces przejmowania innych skandynawskich spółek IT, tak aby docelowo powiększyć zakres swojego działania, jak i portfolio klientów.

Jeszcze w 2006 r. Cybercom rozpoczyna działalność w Indiach, tworząc spółkę joint venture z Datamatics Ltd w Mumbaju. W latach 2007-2008 Cybercom przejmuje dwie firmy - auSystems oraz Plenware. Wraz z tą pierwszą, oprócz oddziałów szwedzkich i duń- 
skich, przejęty został również oddział polski, który od tego momentu nosi nazwę Cybercom Poland. Dzięki pierwszej z przejętych firm - auSystems, liczącej ponad 700 pracowników, spółka znacząco powiększa swoją wielkość, przekraczając po raz pierwszy w historii liczbę 1000 pracowników. Przejęcie drugiej, Plenware - fińskiej spółki IT, operującej również w Chinach, Rumunii i Estonii, poszerzyło portfolio Cybercomu o globalnych graczy rynku telekomunikacyjnego wywodzących się z Finlandii - firmy Nokia i Nokia Siemens Networks. Dzięki temu przejęciu Cybercom w 2008 r. mógł pochwalić się szeroko zakrojoną współpracą ze wszystkimi globalnymi nordyckimi graczami. Dzięki Plenware Cybercom zyskał dostęp do kolejnych gigantów rynku telekomunikacyjnego i w 2008 r. jego kluczowymi klientami stały się: Sony Ericsson, Ericsson, Nokia i Nokia Siemens Networks.

Kolejne lata przyniosły jeszcze kilka mniejszych przejęć, ale przede wszystkim okres ten przypadł na zapoczątkowany w USA kryzys, który bardzo mocno odbił się także na rynku telekomunikacyjnym.

W latach 2009-2010 spółka zmniejszyła swoje zatrudnienie w większości swoich oddziałów. Największe cięcia dotknęły oddziały szwedzkie i fińskie, a jest to ściśle powiązane z kłopotami dziś już nieistniejących firm Sony Ericsson, a także obu Nokii.

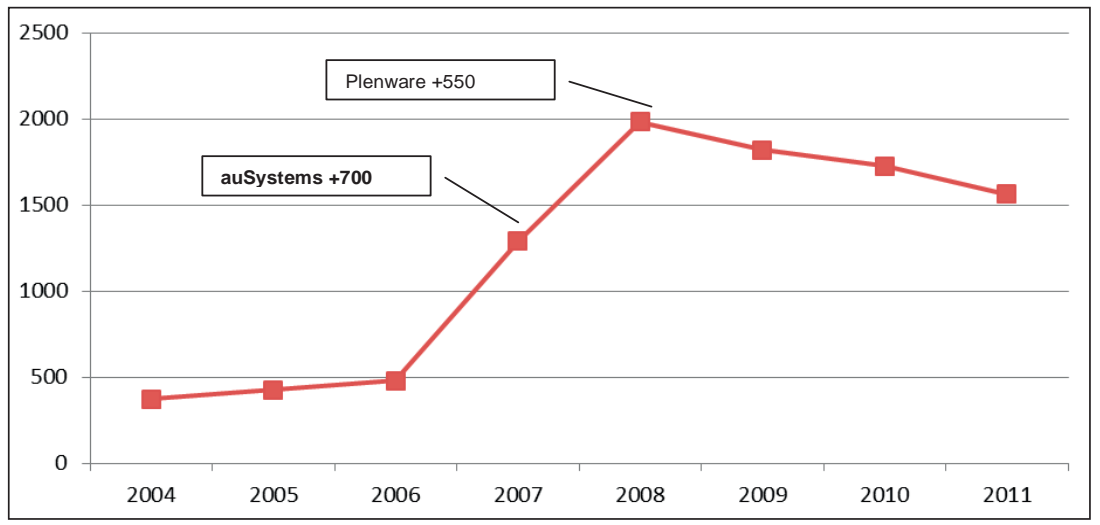

Wykres 3. Wielkość zatrudnienia w latach 2004-2011 i główne przejęcia w okresie 2007-2008 - pierwsze lata w grupie Cybercom

Źródło: opracowanie własne 
Są to również lata ważne dla spółki, która wymaga reorganizacji, gdyż na początku roku 2009 wciąż była konglomeratem 3 podobnej wielkości firm - Cybercomu, auSystems i Plenware. Celem tych zmian miała być jedna, centralnie zarządzana, silna grupa IT. W latach 2010-2012 w ramach centralizacji spółki zniknęly oddziały, które nie do końca wpisywały się w strategię grupy jako całości - oddziały w Estonii, Chinach i Rumunii. W kolejnych latach dostarczaniem wewnętrznych usług $\mathrm{w}$ ramach grupy mieli zajmować się wyłącznie inżynierowie z Polski i z Indii.

\section{7-2008 - pierwsze lata w grupie Cybercom}

W lutym 2007 r. spółkę przejął nowy dyrektor zarządzający, wskazany przez Cybercom Group, wcześniej pracujący jako menedżer w jednej z jej szwedzkich spółek. Głównym jego zadaniem było przystosowanie usług firmy do sektorów obsługiwanych przez grupę. Zadaniem spółki było natomiast dostarczanie usług na rzecz nowego właściciela, przy jednoczesnym założeniu kierowania do spółki polskiej zamówień ze szwedzkich oddziałów. Celem równoległym była budowa lokalnego rynku dla spółki w Polsce.

W obu przypadkach pierwotne założenia, z różnych przyczyn, nie powiodły się. O ile udała się, dzięki dużej elastyczności młodego zespołu informatyków, transformacja technologiczna, o tyle transformacja grupy działającej dotychczas wyłącznie na rynku szwedzkim w firmę globalną, zdolną wykorzystywać swoje zasoby w krajach rozwijających się, okazała się znacznie wolniejszym procesem, który de facto trwał kilka lat. Spółka polska została z dnia na dzień odcięta od nowych zamówień poprzedniego właściciela, a okres ważności dotychczasowych kontraktów nie wystarczył do skutecznego pozyskania nowych kontraktów, w tym kontraktów od restrukturyzującej się grupy. Pierwsze nowe znaczące kontrakty z grupy Cybercom pojawiły się dopiero dwa lata od przejęcia, jesienią $2009 \mathrm{r}$. 
Nie powiódł się również w pierwszych latach rozwój rynku lokalnego. Złożyło się na to kilka przyczyn. Kluczową z nich była niewątpliwie nieznajomość rynku polskiego przez szwedzkiego menedżera. Specyfika polskiego rynku IT w pierwszej dekadzie tego wieku była znacząco inna niż specyfika rynku skandynawskiego. Ważną cechą tego rynku jest bardzo rozpowszechniona kultura wykorzystywania konsultantów IT przez firmy posiadające centra R\&D czy producentów oprogramowania. W związku z tym stosunkowo niska jest tam bariera wejścia na rynek z podobną usługą. Zupełnie inaczej miała się rzecz w Polsce. W tym czasie był to rynek producentów oprogramowania, od małych po ogólnopolskie spółki dostarczające systemy na poziomie krajowym. Duży udział w rynku mieli także międzynarodowi dostawcy sprzętu i oprogramowania, które pozostawiało jedynie pole do integracji i wdrożeń. O ile istniał już popyt na rozwiązania dedykowane, o tyle stosunkowo nierozwinięty był bardzo rozpowszechniony rynek wynajmu zasobów, na którym próbowała zaistnieć również spółka polska.

Nie bez wpływu pozostawał także dość częsty rebranding firmy (w związku ze zmianami właścicieli na przestrzeni kilku lat), a co za tym idzie słaba rozpoznawalność marki Cybercom na rynku lokalnym, która wtedy w oczach potencjalnych klientów była młodą i dopiero dojrzewającą firmą.

Wszystkie te powody doprowadziły spółkę do konieczności zmodyfikowania strategii i większego niż zakładano udziału wytwarzania produktów dedykowanych w całkowitej ofercie firmy. Dopiero taka zmiana jakościowa pozwoliła spółce zacząć konkurować na rynku polskim. Jednakże wiązało się to również $\mathrm{z}$ większym ryzykiem i mniejszą dochodowością projektów w pierwszym okresie tworzenia portfolio klientów.

Ważnym wtedy czynnikiem ryzyka, który przyczynił się do niepowodzeń Cybercomu w Polsce w pierwszych latach jego działalności, był fakt, że stare kontrakty, które stanowiły większościową część portfela zamówień firmy, zostały podpisane w latach ubiegłych, przed wyraźnym wzmocnieniem złotego.

Wszystkie te czynniki przełożyły się na złą kondycję firmy w drugim roku działania pod szyldem Cybercom, bo o ile w roku 2007 spółka wyraźnie korzystała jeszcze z kontraktów zawartych w przededniu 
przejęcia przez Cybercom, o tyle w 2008 r. bardzo wyraźnie dał się odczuć brak nowych klientów i zamówień, co wraz z kończeniem się wcześniejszych kontraktów i wzmiankowanym problemem kursowym doprowadziło do zapaści finansowej w drugiej połowie roku 2008 i zakończyło współpracę spółki z dotychczasowym dyrektorem zarządzającym.

\section{Wpływ waluty na kondycję spółki}

W latach 2007-2008 spółka w bardzo dotkliwy sposób odczuwała silne umocnienie złotego, który w 2008 r. uzyskiwał historyczne szczyty w stosunku do kluczowych walut, a w szczególności do euro, co widać na wykresie 4.

Wzrost wartości złotego względem euro wpłynął negatywnie na rentowność eksportu, co skutkowało wyraźnym zmniejszeniem jego dynamiki. O ile we wcześniejszych latach polski oddział był beneficjentem stosunkowo słabej waluty, to jako eksporter, prawie całkowicie skazany na kontrakty walutowe, bardzo negatywnie odczuł prosperitę złotego. Kilkudziesięcioprocentowe umocnienie kursu złotego spowodowało, że intratne dotychczas kontrakty nie tylko nie przynosiły zysku, ale zaczęły wręcz generować stratę.

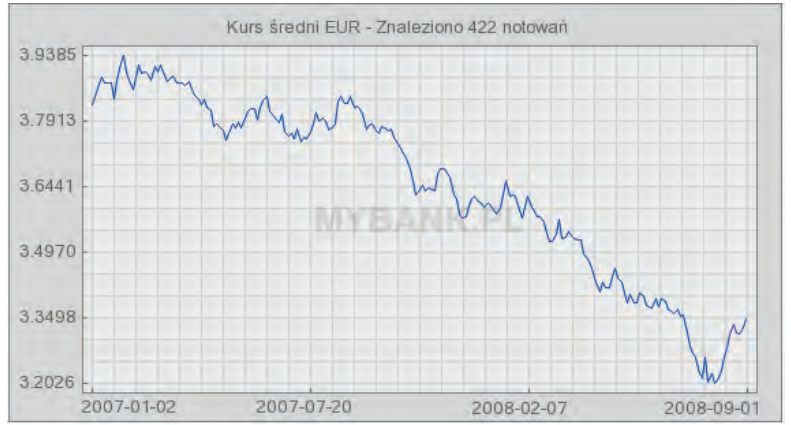

Wykres 4. Średni kurs euro w latach 2007-2008

Źródło: mybank.pl 


\section{Nowa era Cybercom w latach 2009-2012}

Rezultatem pogłębiających się problemów finansowych spółki było zakończenie współpracy z dotychczasowym dyrektorem zarządzającym oraz przejęcie tej funkcji, w październiku 2009 r., przez Piotra Ciskiego. Przejęcie spółki przez nowego dyrektora zarządzającego nastąpiło w czasie, gdy sytuacja finansowa Cybercom Poland była bardzo niekorzystna, co wiązało się z koniecznością przeprowadzenia dogłębnych zmian w przedsiębiorstwie. Pogarszające się wyniki finansowe przedsiębiorstwa były spowodowane przez kilka czynników. Jednym z kluczowych okazała się zmiana sposobu realizacji projektów offshoringowych wewnątrz grupy, będąca następstwem licznych akwizycji dokonywanych przez Cybercom Group. W wyniku tych przejęć w grupie znalazły się spółki działające w Estonii, Rumunii, Polsce, Chinach oraz Indiach, co skutkowało wytworzeniem się wewnętrznego rynku i wzmogło wewnętrzną konkurencję pomiędzy spółkami. Przedsiębiorstwa te zaczęły tworzyć centra kompetencyjne według własnego uznania, co spowodowało, że zaczęły oferować takie same usługi (brak specjalizacji). Problem, który się w związku z tym narodził, dotyczył rozdzielenia projektów pomiędzy konkurujące spółki. O przydziale tym w dużej mierze decydowały względy nieformalne, np. jeżeli spółka fińska przed zakupem posiadała spółki w Estonii i Rumunii, to w ramach grupy w dalszym ciągu utrzymywała bardzo bliskie relacje z tymi spółkami i to właśnie tam trafiały przede wszystkim projekty offshoringowe, które były sprzedawane Finlandii. Cybercom stanął przed bardzo poważnym wyzwaniem wypracowania spójnej i skoordynowanej polityki tworzenia tzw. centrów kompetencyjnych.

Innym, równie znaczącym problemem była niewielka liczba realizowanych projektów oraz bardzo słabo rozwinięta sprzedaż na rynku lokalnym. Cybercom Poland w tym czasie miał jedynie 3 dużych klientów: NSN, Teleca oraz Cybercom Sweden. 


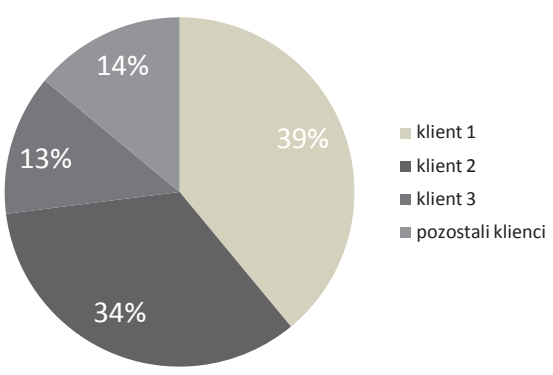

Wykres 5. Udział poszczególnych klientów w sprzedaży eksportowej firmy w $2009 \mathrm{r}$.

Źródło: opracowanie własne

Brak dywersyfikacji bazy klientów wystawiał spółkę na poważne ryzyko operacyjne, a utrata bądź spadek zamówień od któregokolwiek z nich bezpośrednio uderzyłyby w wyniki przedsiębiorstwa. Dodatkowo pojawiały się problemy administracyjne i kadrowe, silny podział na biuro łódzkie i warszawskie, a także powiększała się strata finansowa, w znacznym stopniu przewyższająca wielkość kapitału. Ponadto nieefektywnie działający zespół sprzedażowy nie był w stanie zmienić niekorzystnej struktury (cele jakościowe) oraz osiągać wymaganego poziomu sprzedaży (cele ilościowe).

Myśląc o stworzeniu spółki, która w dłuższej perspektywie czasu miałaby przynosić dochody, koniecznie należało przeprowadzić proces restrukturyzacji. Niezbędne było ograniczenie zatrudnienia w administracji oraz wśród konsultantów (redukcja mało konkurencyjnych lub niepasujących do profilu firmy kompetencji) i budowa od podstaw działu sprzedaży. Proces ten trwał około roku. Na koniec 2009 r. spółka w dalszym ciągu odnotowywała stratę, była to jednak strata założona w planie finansowym przedsiębiorstwa. Dzięki porozumieniu z głównym udziałowcem Cybercom Poland nastąpiło podniesienie kapitału oraz firma uzyskała dofinansowanie na dokonanie procesu restrukturyzacji.

W roku 2010 nowo powstały dział sprzedaży zaczął przynosić pierwsze efekty. Początkowo w dużej mierze sprzedaż opierała się na dyrektorze zarządzającym oraz innych menedżerach, a w miarę upływu czasu firma poszerzała bazę klientów i pozyskiwała nowe kontakty 
biznesowe. Spadek zamówień od NSN i Teleca rekompensowany był nowymi zamówieniami ze strony Cybercom Sweden oraz rozwojem sprzedaży na rynku polskim.

W roku 2010, dzięki gruntownej analizie dostępnych w firmie kompetencji, nastąpiło znaczne polepszenie oferty. Równie istotne okazało się podjęcie decyzji o tym, co będzie stanowiło unikalną ofertę dla klienta (key selling point). W tym roku firma bardzo mocno postawiła na rozwój aplikacji mobilnych: Android, iOS, Blackberry, ale także na Migo oraz Samsung Bada, które zyskiwały coraz większą popularność na rynku. Dodatkowo wzmocnione zostały kompetencje w obrębie Javy i serwerów aplikacyjnych oraz standardowych rozwiązań opartych na językach Net i C/C++. Dodatkowo pod koniec 2009 r. firma przejęła niewielki zespół Ericssona, który zajmował się bardzo ciekawą i nowoczesną technologią, a mianowicie rozwiązaniami dla urządzeń dostępowych instalowanych $\mathrm{w}$ telefonach, tabletach i komputerach przenośnych. Rok 2010 był dla firmy rokiem przełomowym. W tym okresie nastąpiła dywersyfikacja sprzedaży oraz rozpoczęło się budowanie nowych kompetencji. Ten rok firma zakończyła z pozytywnym wynikiem finansowym i znacznie poszerzoną bazą klientów.

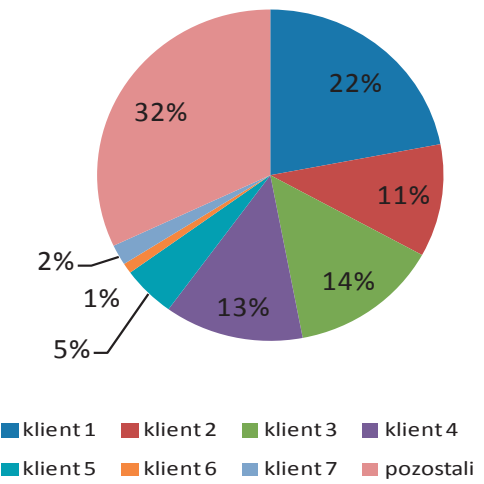

Wykres 6. Udział poszczególnych klientów w sprzedaży eksportowej firmy w roku 2010

Źródło: opracowanie własne 
Efektywna sprzedaż, profesjonalne podejście do wykonywanych projektów oraz świadczonych usług, poprawa zarządzania zasobami ludzkimi oraz wypracowany na koniec roku zysk - wszystko to sprawiło, że rok 2011 był jednym z najlepszych lat w spółce. W tym okresie zmianie uległa struktura przychodów firmy: 55\% przychodów pochodziło z projektów offshoringowych, $45 \%$ ze sprzedaży będącej wynikiem lokalnych działań sprzedażowych. W tym czasie baza klientów firmy uległa znacznemu poszerzeniu. Warto pamiętać, że w roku 2011 cała Europa odczuwała spowolnienie gospodarcze, Polska jako jeden z niewielu krajów europejskich odnotowała wzrost PKB. W tym okresie polska spółka Cybercom osiągnęła docelową strukturę, której budowanie zajęło dwa lata. Kluczową rolę odegrała tu dywersyfikacja sprzedaży - Polska zaczęła odnosić sukcesy w sprzedaży na rynku lokalnym. Dzięki temu na koniec 2011 r. spółka odnotowała jeden z najlepszych wyników w całej grupie Cybercom.

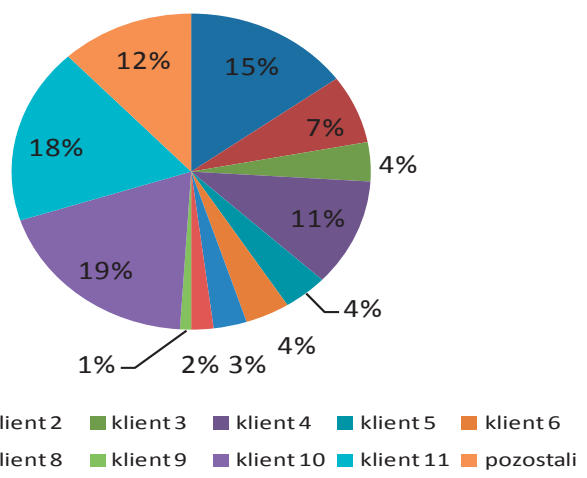

Wykres 7. Udział poszczególnych klientów w sprzedaży eksportowej firmy w roku 2011

Źródło: opracowanie własne

Bardzo dobre wyniki firmy spowodowały, że Cybercom Poland stał się wiodącą spółką offshoringową w grupie. Posiadająca podobną bazę kosztową spółka w Rumunii nie odnotowała takich sukcesów jak Pol- 
ska, co w rezultacie doprowadziło do zamknięcia tej spółki przez zarząd Cybercom Group i przeniesienia pozostałych tam projektów do Polski. Drugą, bardzo ważną przesłanką decydującą o przeniesieniu projektów do Polski była potrzeba zbudowania spółki, która z jednej strony świadczy usługi offshoringowe, a $\mathrm{z}$ drugiej posiada odpowiednią masę krytyczną, czyli odpowiednią liczbę konsultantów, niezbędną do podejmowania się dużych i skomplikowanych projektów informatycznych.

Zbudowany od podstaw nowy zespół sprzedażowy zintensyfikował działania na polskim rynku, co zaowocowało wzrostem sprzedaży o $23 \%$ w 2010 r. (w porównaniu do roku ubiegłego) oraz wzrostem o kolejne $15 \%$ w 2011 r. Poprawa kondycji firmy była możliwa dzięki optymalnemu wykorzystaniu warunków rynkowych oraz stworzeniu stabilnego modelu, bazującego na równowadze pomiędzy sprzedażą lokalną a sprzedażą do grupy. W 2012 r. Cybercom Poland wypracował najlepszy wynik finansowy w całej grupie. Jak widać na wykresie 8 , firma od roku 2010 utrzymuje stały wzrost i przewiduje utrzymanie tej tendencji w kolejnych latach.

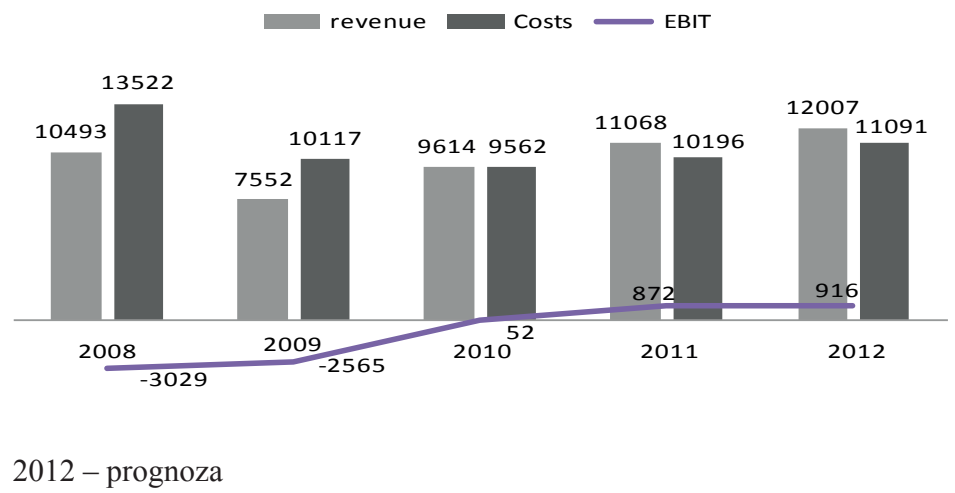

Wykres 8. Wyniki finansowe spółki w latach 2008-2012

Źródło: opracowanie własne

Niezwykle istotna z punktu widzenia długofalowego rozwoju firmy jest koncentracja na planowaniu strategicznym. Wypracowanie w 2009 r. i kontynuowanie przez kolejne lata strategii rynkowej firmy 
było podstawowym krokiem w kierunku zbudowania efektywnego modelu biznesowego. Bardzo trudnym, aczkolwiek nieuniknionym etapem był przeprowadzony proces restrukturyzacji (redukcja zatrudnienia o $23 \%$ ). W rezultacie przyczynił się on do wzrostu firmy oraz podniesienia jej efektowności operacyjnej, m.in. dzięki powstałemu od podstaw zespołowi sprzedaży. Bardzo istotne dla sukcesu firmy okazało się polepszenie oferty w roku 2010, skoncentrowanie się na wybranych technologiach oraz określenie tzw. key selling point. Firma uzyskała znacznie większą autonomię a dzięki spójnej strategii mogła znacznie zwiększyć efektywność w wybranych przez siebie obszarach. Nie udałoby się wypracować tak skrupulatnie przygotowanej strategii, gdyby nie determinacja menedżmentu, który potrafił sprostać pojawiającym się wyzwaniom i zapewnić firmie stabilność. Wszystkie te czynniki wpłynęły na kondycję firmy i kształt, jaki posiada obecnie. 